\title{
Recognition of potential morbidity after use of the radial artery as a conduit for coronary artery revascularization
}

\author{
Geoffrey G Hallock MD
}

\begin{abstract}
GG Hallock. Recognition of potential morbidity after use of the radial artery as a conduit for coronary artery revascularization. Can J Plast Surg 2003;11(2):67-69.

The use of the radial artery as an alternative vascular conduit for coronary bypass surgery has become increasingly popular. The plastic surgery experience with radial forearm flaps has shown that sacrifice of the radial artery is not always a benign maneuver. The potential morbidity after using this conduit donor site in terms of hand dysfunction or wound healing problems can be significant, and frequently must ultimately be addressed as part of the role of the reconstructive surgeon. Case examples of skin necrosis, subsequent forearm wound infection and hypertrophic scarring after radial artery harvest are presented to introduce this as a real concern and to allow a review of the entire spectrum of potential problems in this regard. Any selection process where the radial artery may be chosen as the coronary revascularization conduit must anticipate these known donor site complications.
\end{abstract}

Key Words: Complications; Coronary artery bypass; Hand morbidity; Radial artery conduit

\section{La constatation d'une morbidité potentielle après l'utilisation de l'artère radiale comme conduit de revascularisation de l'artère coronaire}

\begin{abstract}
L'utilisation de l'artère radiale comme conduit vasculaire de rechange dans le cadre d'un pontage coronarien gagne en popularité. L'expérience de la chirurgie plastique au moyen de lambeaux radiaux de l'avant-bras démontre toutefois que le sacrifice de l'artère radiale n'est pas toujours une manœuvre bénigne. La morbidité potentielle après l'utilisation de cette zone de prélèvement en ce qui a trait à la dysfonction de la main ou de problèmes de cicatrisation de la plaie peut être importante, et il faut souvent recourir à la chirurgie reconstructive. Des exemples de cas de nécrose cutanée, d'infection subséquente de la plaie à l'avant-bras et de cicatrisation hypertrophique après le prélèvement de l'artère radiale sont présentés pour démontrer qu'il s'agit là d'une véritable préoccupation et pour permettre de réviser tout le spectre de problèmes potentiels s'y rapportant. Dans tout processus de sélection qui oblige à choisir l'artère radiale comme conduit de revascularisation coronaire, il faut prévoir ce type de complications dans la zone de prélèvement.
\end{abstract}

$I^{\text {n }}$ n the search for other types of conduits to complement the standard left internal mammary artery (IMA) for coronary artery revascularization, the radial artery was first considered in 1971 (1). Soon thereafter, this was abandoned due to a presumed high incidence of bypass narrowing from vasospasm or frank occlusion (1). However, in the late 1980's there was a revival of interest in using the radial artery, which coincided with the development of newer pharmocological antispasmodic agents and minimally traumatic harvesting techniques $(1,2)$. The radial artery is now considered an excellent conduit alternative as an arterial graft is used to systemic pressure regimens with superior flow characteristics; the mean calibre is larger than the IMA and equivalent to most coronary arteries; thickness and wall quality allow technically easy anastomoses; available length permits reaching all target vessels on the heart's surface; and short and mid term patency rates exceed that of vein grafts $(1,3,4)$.

Unlike the donor site morbidity from use of lower extremity vein grafts, which is relatively common and readily treatable (5), alteration of hand function or viability from sacrifice of a major inflow source could be much more catastrophic. The long term experience of the plastic surgery community in incorporating the radial vessels as a composite vascular pedicle (6) or part of a forearm flap as introduced by Yang et al (7) should be heeded. Anatomical variations of the circulation to the hand should be anticipated (8-13). Radial artery predominance, an incomplete superficial palmer arch, and malformations of the ulnar artery, whether all congenital or acquired due to peripheral vascular disease common to this subset of patients, may impair hemodynamic compensation after radial artery removal (14). Acute global hand ischemia has been reported after raising a radial forearm flap, requiring an emergency interposition vein graft for restoration of hand circulation (15), although usually a vein graft is not necessary (16) even if upper limb blood flow measurements with Technetium ${ }^{99 m}$ isotope tissue perfusion show diminished postoperative flow to the operated extremity (4).

Delayed healing, hand swelling and stiffness, reduced hand grip and pinch strength, dysesthesias, cold induced intolerance and decreased digital temperatures have all been observed after the elevation of a radial forearm flap (17-19). Resolution of these residual symptoms sometimes has taxed our ingenuity, and would be expected to eventually be needed to assist our cardiovascular colleagues when similar untoward events occur

Division of Plastic Surgery, The Lehigh Valley Hospital, Allentown, Pennsylvania, USA

Correspondence: Dr Geoffrey G Hallock, 1230 South Cedar Crest Boulevard, Suite 306, Allentown, Pennsylvania 18103, USA.

Telephone 610-435-7555, fax610-770-6390,e-mail pbhallock@cs.com 


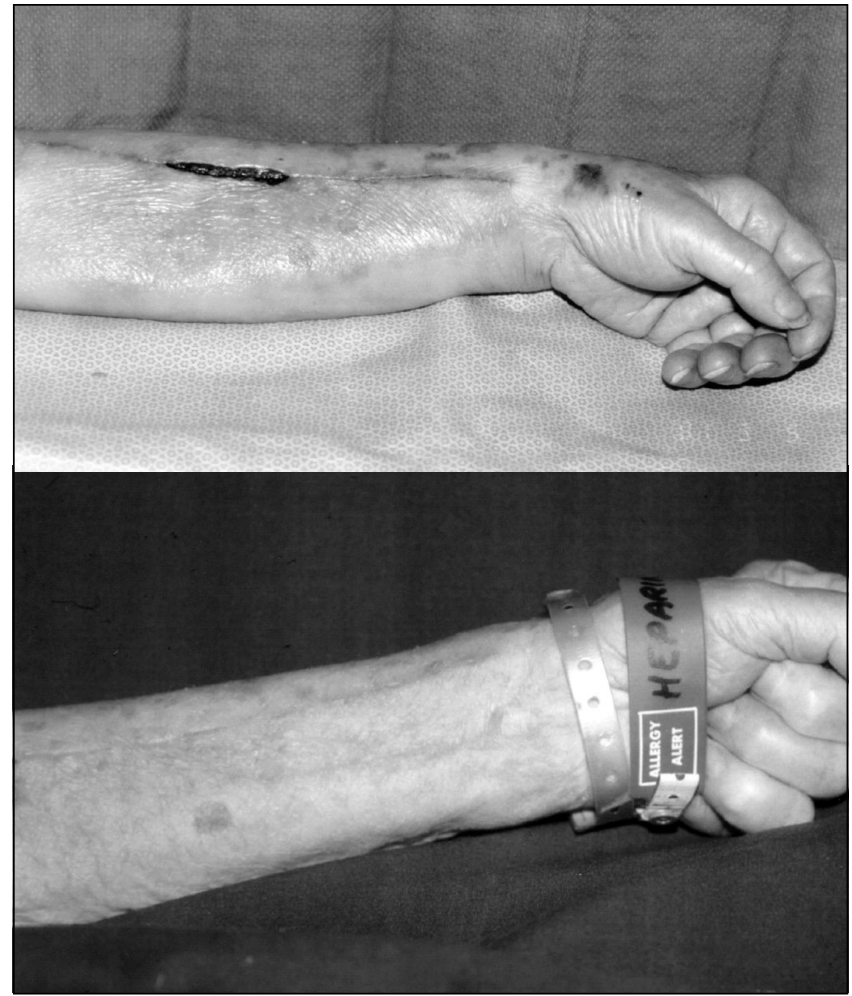

Figure 1) Top: granulating, partially open left forearm wound after serial debridement of necrotic skin and fat; Bottom: healed radial artery donor site after secondary closure

after radial artery harvest alone. Two relatively minor incidents are reported in the present paper to emphasize the potential liability of this conduit donor site, and foster a better awareness of this potential problem.

\section{METHODS AND RESULTS}

The true incidence of complications after radial artery harvest for coronary revascularization at The Lehigh Valley Hospital, Allentown, Pennsylvania is unknown, because the majority of problems are suspected to be minor. Two clinical examples are presented that depict common sequela that happened to have had plastic surgery consultation.

\section{CASE PRESENTATIONS}

\section{Case 1: Skin necrosis}

An 80-year-old diabetic man with chronic renal insufficiency underwent an uneventful coronary artery bypass graft with left IMA and left radial artery conduits harvested in the 'usual fashion'. Eleven days later he was readmitted with an overwelming sternal wound infection and noted to have a left forearm infection due to skin and fat necrosis (Figure 1). Serial debridement of all wounds, a left pectoralis major muscle flap to close the mediastinal wound, and later secondary closure of the forearm wound resulted in eventual healing at the time of the patient's discharge four months later.

\section{Case 2: Hypertrophic scar}

A somewhat obese, relatively young 50-year-old diabetic woman, following coronary artery bypass graft with use of the

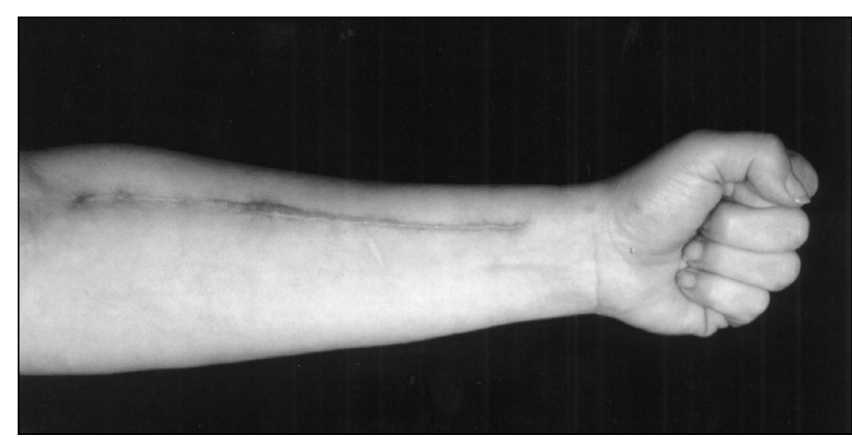

Figure 2) Raised, tender hypertrophic scar that developed at the left forearm radial artery donor site

left IMA, left radial artery and left greater saphenous vein grafts for conduits, developed a sternal wound infection requiring closure after debridement with a left pectoralis major muscle flap. Her left forearm donor site healed uneventfully. Four months later, however, it was noted that both her median sternotomy incision and left forearm donor site had developed bothersome hypertrophic scars (Figure 2). She refused steroid injections, and was treated instead with silicone sheeting. She did not return for further follow-up.

\section{DISCUSSION}

Although the ulnar artery is usually the dominant supply to the superficial palmer arch and ultimately the digits $(20,21)$, digital plethysmography pulse-volume recordings with concomitant radial artery compression have shown that $28 \%$ of patients considered for heart bypass surgery lost thumb perfusion, and $9 \%$ of hands had radial predominance (3). This variability can be attributed to not only congenital anomalies $(14,20,21)$, but also to acquired alterations, as vascular stenoses and occlusions would not be uncommon due to coexisting peripheral vascular disease. Patient selection criteria for use of the radial artery as a conduit must therefore be stringent to minimize especially ischemic sequela, which in the cardiovascular literature has already included obvious acute hand ischemia $(22,23)$, or exercise induced ischemia (claudication) $(24,25)$ where patients were asymptomatic during normal activities. Skin necrosis (Figure 1) and subsequent wound infection or vice versa may be more subtle examples of ischemic induced sequela. The lack of ulnar artery perforators or other collaterals to the forearm fascia, either pre-existing or due to degeneration or surgical trauma, could result in such a relative localized skin ischemia (11).

The most common source of morbidity after radial artery conduit harvest has been neurological complaints in 30\% of patients, with $12 \%$ having long term residua (26). Iatrogenic trauma such as retraction on the lateral antebrachial cutaneous nerve coursing with the cephalic vein in the proximal forearm, or on the brachioradialis muscle with the underlying superficial branch of the radial nerve, have caused dysesthesias in their corresponding dermatome $(1-3,26)$. Because the lower lateral cutaneus nerve of the arm branch of the superficial sensory radial nerve courses distinctly with the radial artery (27), nerve injury during artery elevation or inadvertent inclusion in a hemoclip while dividing vascular side branches (personal communication) could occur. It has also been postulated that thumb weakness could be due to malfunction of the flexor pol- 
TABLE 1

Reported upper extremity complications after the harvest of a radial artery conduit

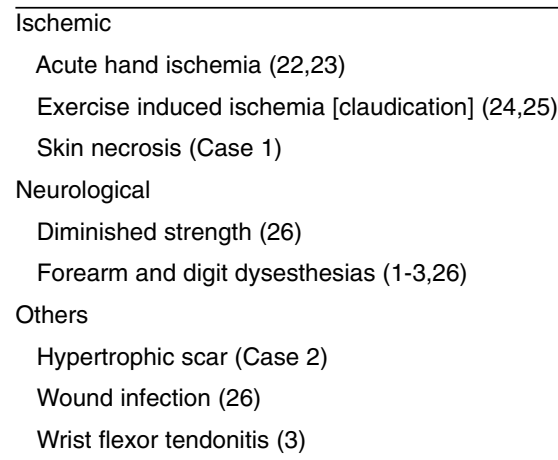

licis longus muscle and/or anterior interosseous nerve on a relative ischemic basis, because both are usually directly nourished by branches of the radial artery (26).

Although the radial artery as a free graft can be a superior complement to the pedicled left IMA for coronary revascularization, indiscriminate use must be discouraged. Significant morbidity to the remaining upper extremity can accrue (Table 1), which must be avoided. Careful preoperative evaluation to ascertain sufficient collateral circulation to the hand and an awareness of other concomitant disease states is of paramount importance to prevent this potential for unintended morbidity.

\section{REFERENCES}

1. Acar C, Jebara VA, Portoghese M, et al. Revival of the radial artery for coronary artery bypass grafting. Ann Thorac Surg 1992;54:652-9.

2. Reyes AT, Frame R, Brodman RF. Technique for harvesting the radial artery as a coronary artery bypass graft. Ann Thorac Surg 1995;59:118-26.

3. Dumanian GA, Segalman K, Mispireta LA, Walsh JA, Hendrickson MF, Wilgis EFS. Radial artery use in bypass grafting does not change digital blood flow or hand function. Ann Thorac Surg 1998;65:1284-7.

4. Sadaba JR, Conroy JL, Burniston M, Maughan J, Munsch C. Effect of radial artery harvesting on tissue perfusion and function of the hand. Cardiovasc Surg 2001;9:378-82.

5. Hallock GG. Vein donor site morbidity after coronary bypass surgery: An overlooked but important issue, Can J Plast Surg 1999;7:117-21.

6. Sukkar SM, Daw JA, Chandler J, Dumanian GA. Gracilis muscle free flap transfer using a radial artery-venae comitantes composite vascular pedicle. Plast Reconstr Surg 2001;108:156-61.
7. Yang GF, Chen BQ, Gao YZ, et al. Classic reprint: Forearm free skin flap transplantation: A report of 56 cases. Br J Plast Surg 1997;50:162-5.

8. Vadodaria S, Brotherston TM, Page RE. Best use of anomaly of radial artery. Br J Plast Surg 2001;54:180-1.

9. Porter CJW, Mellow CG. Anatomically aberrant forearm arteries: An absent radial artery with co-dominant median and ulnar arteries. Br J Plast Surg 2001;54:727-8.

10. Mordick TG. Vascular variation of the radial forearm flap: A case report. J Reconstr Microsurg 1995;11:345-6.

11. Madaree A, McGibbon IC. Anatomic variation in the blood supply of the radial forearm flap. J Reconstr Microsurg 1993;9:277-9.

12. Small JO, Millar R. The radial artery forearm flap: An anomaly of the radial artery. Br J Plast Surg 1985;38:501-3.

13. Devansh D. Superficial ulnar artery flap. Plast Reconstr Surg 1996;97:420-6

14. Pola P, Serricchio M, Flore R, Manasse E, Favuzzi A, Possati GF. Safe removal of the radial artery for myocardial revascularization: A Doppler study to prevent ischemic complications to the hand. J Thorac Cardiovasc Surg 1996;112:737-44.

15. Jones BM, O'Brien CJ. Acute ischaemia of the hand resulting from elevation of a radial forearm flap. Br J Plast Surg 1985;38:396-7.

16. Meland NB, Core GB, Hoverman VR. The radial forearm flap donor site: Should we vein graft the artery? A comparative study. Plast Reconstr Surg 1993;91:865-70.

17. Kleinman WB, O'Connell SJ. Effects of the fasciocutaneous radial forearm flap on vascularity of the hand. J Hand Surg 1993;18:953-8.

18. Timmons MJ, Missotten FEM, Poole MD, Davies DM. Complications of radial forearm flap donor sites. Br J Plast Surg 1986;39:176-8.

19. Richardson D, Fisher SE, Vaughan ED, Brown JS. Radial forearm flap donor-site complications and morbidity: A prospective study. Plast Reconstr Surg 1997;99:109-15.

20. Ruengsakulrach P, Eizenberg N, Fahrer C, Fahrer M, Buxton BF. Surgical implications of variations in hand collateral circulation: Anatomy revisited. J Thorac Cardiovasc Surg 2001;122:682-6.

21. Ruengsakulrach P, Buxton BF, Eizenberg N, Fahrer M. Anatomic assessment of hand circulation in harvesting the radial artery. J Thorac Cardiovasc Surg 2001;122:178-80.

22. Nunoo-Mensah J. An unexpected complication after harvesting of the radial artery for coronary artery bypass grafting. Ann Thorac Surg 1998;66:629-31.

23. Fox AD, Whiteley MS, Phillips-Hughes J, Roake J. Acute upper limb ischemia: A complication of coronary artery bypass grafting. Ann Thorac Surg 1999;67:535-6.

24. Coltharp WA. Revival of the radial artery for coronary artery bypass grafting. Ann Thorac Surg 1992;54:659-60.

25. Serricchio Gaudino M, Tondi P, Gasbarrini A, et al. Hemodynamic and functional consequences of radial artery removal for coronary artery bypass grafting. Amer J Cardiol 1999;84:1353-6.

26. Denton TA, Trento L, Cohen M, et al. Radial artery harvesting for coronary bypass operations: Neurologic complications and their potential mechanisms. J Thorac Cardiovasc Surg 2001;121:951-6.

27. Boutros S, Yuksel E, Weinfeld AB, Alford EL, Netscher DT. Neural anatomy of the radial forearm flap. Annal Plast Surg 2000;44:375-80. 